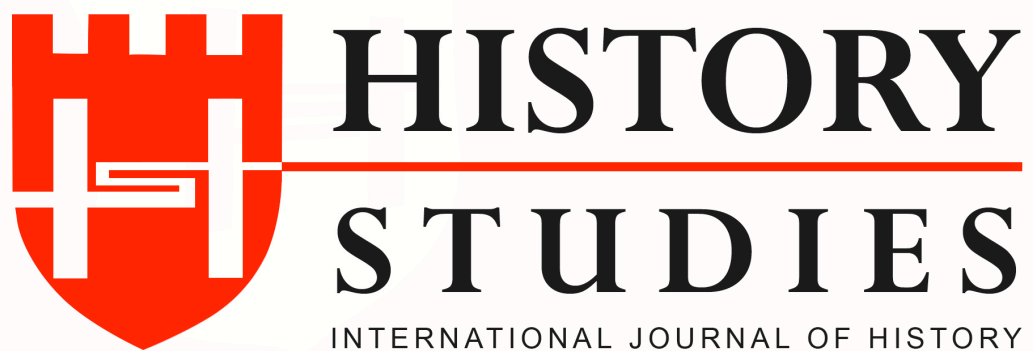

ISSN: 13094173 (Online) 1309 - 4688 (Print)

Volume 11 Issue 4, August 2019

DOI Number: 10.9737/hist.2019.764

Araştırma Makalesi

Makalenin Geliş Tarihi: 02.08.2019 Kabul Tarihi: 20.08.2019

Atıf Künyesi: M. Mücahit Küçükyilmaz, “First Rallies in Our Multi-Party Political Communication History: Addresses by İsmet Pasha in Sivas and Fethi Bey in İzmir", History Studies, 11/4, Ağustos

2019, s. 1285-1297.

\title{
FIRST RALLIES IN OUR MULTI-PARTY POLITICAL COMMUNICATION HISTORY: ADDRESSES by ISMET PASHA in SIVAS and FETHI BEY in IZMIR
}

\section{Çok Partili Siyasal İletişim Tarihimizin İlk Mitingleri: İsmet Paşa'nın Sivas ve Fethi Bey'in İzmir Konuş̧maları}

\author{
Dr. M. Mücahit KÜÇÜKYILMAZ \\ ORCID No: 0000-0003-2902-3719 \\ T.C. Cumhurbaşkanlı̆ $\breve{l}$
}

Öz: Kasım 1924 ile Haziran 1925 arası yaklaşık 7 ay yaşayan Terakkiperver Cumhuriyet Firkas1 sonrası, ikinci kez bir muhalefet partisinin kurulması Ağustos 1930'da gerçekleşmiştir. Aynı zamanda Eylül-Ekim 1930'da gerçekleşen ve 1,5 aydan fazla süren ilk mahalli seçimlere katılan Serbest Cumhuriyet Fırkası (SCF) döneminde Cumhuriyet Halk Fırkası (CHF) Lideri İsmet Paşa'nın Sivas ve SCF Lideri Fethi Bey'in İzmir mitingleri cereyan etmiştir. Liderlerin konuşmalarında gerek halkla yüz yüze bir iletişim sağlanması açısından "doğrudan", gerekse konuşma metinlerinin tamamının dönemin önde gelen gazetelerinde yayınlanarak mekânda hazır bulunmayan kitleye de ulaştırılması açısından "dolaylı" iletişim yöntemleri bir arada kullanılmışıtır. Bu bakımdan, Türkiye'de çok partili siyasal yaşamın ilk meydan toplantıları sayılabilecek bu mitinglerde, hem ele alınan konular, hem de bunların ele alınış biçimi söylem analizi ve siyasal iletişim teknikleri açısından önemli veriler sunmaktadır. Arşiv araştırmasına dayanan ve karşılaştırmalı söylem analizi yöntemini kullanan bu makalede, dönemin siyasal kültürü, ideolojik tutumları, güncel konuları ve liderlerin meydan performansları üzerinde durulmaktadır.

Anahtar Kelimeler: Siyasal iletişim, SCF, CHF, Sivas ve İzmir meydan mitingleri, dolaylı iletişim, doğrudan iletişim.

\begin{abstract}
Following the short-lived Progressive Republican Party, which lasted only 7 months between November 1924 and June 1925, a second opposition party was founded in August 1930. During the period of the Liberal Republican Party, which ran in the first local elections that was held in September-October 1930 and lasted for 1.5 months, the leader of the Republican People's Party, İsmet Pasha, held a rally in Sivas and the leader of the Liberal Republican Party, Fethi Bey, held one in Izmir. Both "direct", in terms of face to face communication with the people, and "indirect", in terms of delivering the speeches to the masses, who were not present in the rallies, by publishing them in the leading newspapers of the era, communication methods were jointly employed in the leaders'
\end{abstract}


addresses. In this regard, the matters, addressed during these rallies, which can be regarded as the first public meetings of the multi-party political life in Turkey, and the way they were addressed offer significant data in terms of discourse analyses and political communication techniques. This article, which is based on archive research and uses comparative discourse analysis method, examines the political culture, ideological attitudes, topical issues and the leaders' public performances.

Key Words: Political Communication, Liberal Republican Party, Republican People's Party, Sivas and İzmir rallies, direct communication, indirect communication.

\section{Introduction}

The existence of a multi-party political life and the participation of various social groups in government are a sine qua non of democracy. The parties, which come to power, govern by taking into account the decisions of the bodies and institutions which ensure the state system functions and also the views and resolutions of the parliament which represent the people's will. At the end of the tenure, people are asked to vote in the elections, and the outcome determines the elected officials of the state. Therefore, the democratic political life requires the relationship between the administrators and the people to be established and maintained in various ways. In this regard, political parties employ two main methods, notably "direct" and "indirect". Among the indirect methods are declarations, visual materials, news and comments which are delivered to the masses through media, and it can be said that they are spread over a "wide" surface but lack the intensity which, in the long run, will lead to a "profound" affect and transformation. Direct methods can be described as face-to-face meetings such as house meetings, rallies, visits to shopkeepers. It can be thought that the second type of communication activities, in comparison with the first one, has the power to cause a "profound" effect in a "narrower" area in the short run and allows closer ties to be established in terms of mobilizing masses towards a goal. Direct communication method naturally requires more personal efforts and patience. However, political structures, which persistently and systematically employ this method, are better at building an organized and solid bodies. For example, Mustafa Kemal, who adopted an indirect communication method in the course of his time in Istanbul during the occupation days which officially started on October 30, 1918, published a newspaper called Minber. However, he, later on, quit his undertaking, departed for Anatolia and engaged in direct communication with the people in order to persuade them to join the movement he was trying to organize against the occupation in regions like Samsun, Amasya, Erzurum and Sivas. In the following period, influential orators such as Celal (Bayar) Bey (a.k.a. Galip Hoca), Mehmet Akif (Ersoy), Halide Edip (Adıvar) and Hamdullah Suphi (Tanriöver) played significant roles in the success of social organization through rallies, sermons and meetings.

The addresses by the leader of the Republican People's Party and Prime Minister, İsmet Pasha, in Sivas (August 30,1930) and by the leader of the Liberal Republican Party, Fethi Bey, in İzmir (September 7, 1930) took place as public speeches and went down in Turkey's political history as the first rallies of the multi-party political life. Archive research method was used in the article and issues of Cumhuriyet daily newspaper, which followed the rallies on site, dated August 31- September 8, 1930 were surveyed. Also, memoirs and historical documents were benefited from. In the second phase of the method, prominent topics in the speeches of İsmet Pasha and Fethi Bey were subjected to comparative discourse analysis. The highlighted discourses on politics, economy, international politics and topical polemics were examined. Both politicians were found to have appeared before the masses well-prepared with powerful 
oratory, well-studied background, ideological depth and rich rhetoric during these rallies, which can be regarded as the firsts of their kind.

\section{Political Opposition and Communications during the Single-Party Era}

The Progressive Republican Party, the first de jure political opposition attempt in the Republican history, lasted only 7 months between November 17, 1924 and June 3, 1925. The process which first led to the neutralization then to the shutdown of the Progressive Republican Party began with the Sheikh Said rebellion that broke out in eastern provinces at the beginning of February 1925. Up until the rebellion, it can be said that the head of government of the Republican People's Party, Fethi Bey, and prominent members of the Progressive Republican Party, notably Rauf (Orbay) Bey, Kazım (Karabekir) and Ali Fuat (Cebesoy) Pashas, enjoyed a refined -so to speak- government-opposition relationship. However, when the Republican People's Party's group replaced Prime Minister Fethi Bey with İsmet Pasha on March 4 and the parliament passed the Law on the Maintenance of Order and decided to reinstate the Independence Courts, it was the beginning of the end for the Progressive Republican Party. It can also be accepted as the beginning of the process which rendered Fethi Bey, who was known for his moderate and liberal character, passive. Fethi Bey departed from Turkey on March 27 to assume his post as the Ambassador to Paris.

The political life in Turkey continued as a single-party system until January 1946 except for the Progressive Republican Party, which lived between November 1924 and June 1925, and the Liberal Republican Party, which lasted between August 1930 and November 1930. (The People's Party, the attempts to establish leftist parties, and the National Development Party can be listed as exceptions. However, it is difficult to accept them as exceptions that may break the rule.) Therefore, the power of the popular vote was limited to a symbolic level since there was a single party which had the power and "party members assumed state responsibilities, for example a provincial party chairman would be appointed governor of his province." ${ }^{1}$ As a result, there lacked the possibility of a real democratic sanction which would force the administrators to use a direct communication method which would require them to establish close ties with the society. In such an opposition-free environment, holding a real and proper rally was naturally regarded unnecessary. Public addresses were only delivered as a necessity on the occasions of national days and opening ceremonies. The short-lived opposition period of the Liberal Republican Party, which began with the "pre-arranged" letters written to each other via the press first by Fethi Bey at the beginning of August 1930 and by Mustafa Kemal 3 days later and ended with a compulsory dissolution on November 17, 1930, can be considered rich in terms of rallies, one of the leading instruments of political communications.

Fethi Bey, who went abroad to serve as an ambassador after being replaced -because he did not responded harsh enough to the Sheikh Said Rebellion in March 1925 and to the Progressive Republican Party's opposition- by İsmet Pasha who, it was believed, would take more radical measures, returned to Turkey in July 1930 for a long-stay. At first, Fethi Bey's intent was to spend his vacation in his country but it turned out differently. During the Ghazi Mustafa Kemal's meetings in Yalova, the decision to establish the Liberal Republican Party was made and its name, programme, even its leading founders were determined. The Ghazi selected Fethi

${ }^{1}$ Feroz Ahmad, The Making of Modern Turkey, (Oxfordshire:Taylor \& Francis e-Library,2003), 62. 
Bey as the party leader. In fact, Mustafa Kemal and Fethi Bey put the finishing touches to the letters, which declared the establishment of the party, together. Subsequently, Fethi Bey's letter, which expressed his desire to go into politics and establish a party, was published in the newspapers on August 11. It was followed by the Ghazi's letter of reply, which assured the said party "within the bounds of the laic republic", on August 12.

This newly-established party, which defined itself as liberal, to the left of the Republican People's Party, gradually started to criticize the policies, implemented by the İsmet Pasha government in the last 5 years. The criticism focused on economic and financial issues as a result of the Great Depression of 1929 whose grave consequences were deeply-felt in the country back in those days. The Republican People's Party government, which had not felt the need to rely on an obvious ideological reference -thanks to the comfort of having no opposition- in the policies it executed until then, could not display a coherent and strong reaction regarding the matters to which Fethi Bey, a known liberal, opposed in the remarks he made to the press in August. The silence continued until İsmet Pasha's speech at the opening ceremony of the Ankara-Sivas railway on August 30, 1930, which coincided with the Victory Day. Prime Minister İsmet Pasha's speech not only responded to the Liberal Republican Party's criticism, which mainly concentrated on economic issues, but also was a turning point in terms of uttering a clear definition (statism) about the ideological nature of the economic policies, the Republican People's Party had implemented until then. ${ }^{2}$ When İsmet Pasha said in Sivas "We are indeed moderate statists in economy", it was the first official declaration that "statist", even if moderate, policies were pursued. One of the following sentences - "What has led us to this direction is our nation's needs and natural inclinations" - distinctly evokes the conviction that "the Turkish nation is statist by nature", mentioned in the book titled Vatandaş İçin Medeni Bilgiler (Civil Information for Citizens). ${ }^{3}$ The book bears the signature of Afet İnan but there are strong signs that it was dictated by Mustafa Kemal. By saying "The elder men in the villages know as well as we do how this thing called state is governed. We should speak by taking into account that there is a prime minister in every village in our country," İsmet Pasha demagogically saluted the countrymen who were made to "actively" work in the construction of the rail way and implied that the members of the Liberal Republican Party, who were criticizing him, should be careful when speaking. And by saying "Liberalism theory is difficult for our country to understand," he tried to create the impression that there was a gap between the Liberal Republican Party, which included liberalism in its programme, and the people.

The speech, İsmet Pasha delivered in Sivas on August 30, 1930 on the occasion of the Victory Day and the opening ceremony of the Ankara-Sivas railway, is also important since it was the first rally in the political history of the Republic of Turkey, during which a ruling party addressed an opposition party. Afterwards, Fethi Bey, who went to İzmir on September 4, made a show of strength under not-so-favorable conditions and addressed a "mighty crowd" of 50 thousand people at "Alsancak Stadium" on September 7 following postponements ${ }^{4}$ and responded, as was expected by the public, ${ }^{5}$ to İsmet Pasha's speech in Sivas. It can be observed that both rallies revolved around mostly the same themes since they were both critical and responsive in nature. The leaders focused on economic and financial issues as a result of the

\footnotetext{
${ }^{2}$ What Ahmet Ağaoğlu writes in this regard is interesting: "Before the speech İsmet Pasha delivered in Samsun (correction, Sivas) neither I nor anyone else had known that the Republican People's Party, of which I was a member, was statist. It was after this speech that the party became statist. However the speech was made after the foundation of the new party (the Liberal Republican Party)." Serbest Firka Hattralarl, p. 41-42.

${ }^{3}$ Afet İnan, Vatandaş İçin Medeni Bilgiler, (İstanbul: Milliyet Matbaası,1930)

${ }^{4}$ Cumhuriyet, September 8, 1930.

${ }^{5}$ Cumhuriyet, September 2, 1930 .
} 
Great Depression of 1929 whose grave consequences were intensely-felt in the country. İsmet Pasha delivered his speech in Sivas, which reflected the overall state of Anatolia, at the other end of the railway, for which he "had suffered for 7 years", and which he saw "as a matter of national unity, national existence and national independence that could bear no delay." Fethi Bey, on the other hand, chose the Aegean Region, which opened up the most to the market economy, and thus most affected by the repression, in order to reply to the Prime Minister. ${ }^{6}$ Back in those days, İzmir was the second biggest city in the country after İstanbul. It was also the most advanced in terms of building its own bourgeoisie. Thanks to its port, the city served as a trade hub between Anatolia and Europe and overseas. It also had been bearing the negative effects of the population exchange since 1923.

\section{Issues Addressed in Sivas and İzmir Rallies}

İsmet Pasha and Fethi Bey, during their speeches in Sivas and İzmir respectively, largely addressed the same issues. As was expected by the press, ${ }^{7}$ the majority of Fethi Bey's speech was prepared to respond to İsmet Pasha. İsmet Pasha's Sivas speech contained more detailed and technical information and was longer than that of Fethi Bey. İsmet Pasha knew the country better than his rival who had been in Paris for over 5 years as Turkey's ambassador, had more political experience and was in a position of power where he had direct access to data, which played a role in the differences between the said speeches. It can be said that both leaders from time to time used discourses, amounting to populism, in order to "win over the people" and due to the aforementioned reasons, İsmet Pasha was more "successful" in this endeavor.

\subsection{The Railway Issue}

The first topic of İsmet Pasha addressed in his speech was the railway issue since the event he spoke was the opening ceremony of Ankara-Sivas railway. "Today is the primary point of ascension in the history of ancient and noble Sivas to development and glorification," said the Prime Minister. He described the railway issue as a matter of survival so much so that he said he "had suffered for 7 years to reach this point" and "when he got weary, he firmly held on to life and politics in an effort to observe today." According to the Pasha, "the railway policy has betaken itself to the national state as the first matter of national unity, national existence and national independence that can bear no delay or consideration of postponement." Therefore it should not be seen as merely an economic issue and its strategic importance in the defense of the homeland should not be ignored. The Cumhuriyet daily which reported the speech with main headings such as "If there had been the Ankara-Erzurum railway, the Europe would not have entered into the Battle of Sakarya", "The Sivas line is the İnönü [Victory] won against the distance that is the enemy of defense!" and "İzmir's defense is achieved with the people of Sivas arriving in İzmir in 24 hours." ${ }^{\prime 8}$ To the Republican People's Party and İsmet Pasha, the railway policies were a military-strategic issue. As can be understood from the emphasis in the headlines, strategic references were made to İzmir, one of the centers of free trade and economic activities. In this context, Fethi Bey's selection of İzmir to reply to İsmet Pasha takes on a distinct meaning. "This precious interest, which is displayed by İzmir, the most significant part of our country in terms of vigilance and economic development... has reinforced our belief that our program here is very felicitous." According that, Fethi Bey's speech mainly focused on economic aspects rather than strategic emphases and replied onsite to the references made in the Sivas speech. Also, by pointing to the Ghazi's gladness and sensitivities regarding the

\footnotetext{
${ }^{6}$ İlhan Tekeli and Selim İlkin, 1929 Dünya Buhranında Türkiye’nin İktisadi Politika Arayışları (Ankara: ODTÜ Yayınları,1983), 165.

${ }^{7}$ Cumhuriyet, September 2-3-4, 1930.

${ }^{8}$ Cumhuriyet, August 31, 1930.
} 
establishment of the Liberal Republican Party both at the begging and at the end of his speech, Fethi Bey tried, in a way, to legitimize his party and leadership against the Republican People's Party and İsmet Pasha.

Mentioning at the beginning of his speech that the Liberal Republican Party emerged from his exchange of letters with the Ghazi, Fethi Bey said "our aim is to eternalize the Republic." "Those who condone the irresponsibility entailed by the single-party administration do not find this new organization compatible with their interests and they do not refrain from talking against our party," Fethi Bey noted and then went on to reply to the claims about the Liberal Republican Party: Among those were claims of "reactionism", that the Liberal Republican Party "would reinstate the Arabic script", that it would make the people "wear fez" again, and that it "would lift taxes". Fethi Bey denied them all. He only said "it is among our principles to relieve certain taxes which go beyond the patience of the people." Noting that his party was sought to be presented as anti-railway, the leader of the Liberal Republican Party said "It has never crossed our minds to deny the benefits of railways in terms of the defense of the homeland and economy." Declaring that they were against the construction of the railways "under rather severe conditions", Fethi Bey said that the funds, "collected by pinching pennies of the people", must be used more carefully and economically. He then pointed, as an example, to the pressure the severe and short-term contracts signed with the Belgian, Swedish and German companies that undertook the construction of the railway put on the current generation. Fethi Bey's last words on the issue reveals his ultimate choice between economy and railway: "Protecting our economic state from any shocks is as important as constructing railways. I can even say that the second duty is above all else." Because, to Fethi Bey, railways were a matter of economy rather than a military-strategic, national issue, and one of the tasks that were part of economic activities.

\subsection{Liberalism-Statism Debate}

By saying during his speech in Sivas that "Liberalism theory is difficult for our country to understand," İsmet Pasha criticized Fethi Bey and the Liberal Republican Party which defined itself to the left of the Republican People's Party and included liberalism in its programme, and tried to create the impression that there was a gap between liberals and the people. Officially declaring for the first time that -somewhat moderate- "statist" policies were pursued by saying "We are indeed moderate statists in economy. What has led us to this direction is our nation's needs and ideological inclinations", giving upon statism altogether and expecting all blessings from capitalists' activities something this country can understand?" Up until then, the Republican People's Party had not needed to rely on any obvious ideological references in its policies, in part because of the comfort of having no opposition. By saying "The elder men in the villages know as well as we do how this thing called state is governed. We should speak by taking into account that there is a prime minister in every village in our country," İsmet Pasha flattered the countrymen who were made to "actively" work in the construction of the rail way and implied that the members of the Liberal Republican Party, who were criticizing him, should be careful when speaking.

\footnotetext{
9 Some newspapers reported that İsmet Pasha said "natural inclinations" instead of "ideological inclinations" The Cumhuriyet daily's August 31, 1930 issue, referred to here, read "ideological inclinations". However, given the context of the speech and the debates back then with regard to "the nature and characteristics of the Turkish people", it seems more reasonable that he said "natural inclinations". Also, the aforementioned Vatandaş Için Medeni Bilgiler (Civil Information for Citizens), which Mustafa Kemal made Afet İnan author, underscores that "the Turkish nation is statist by nature". In this regard, it is clear that the semantic relationship between nature and natural is stronger than the relationship between nature and idea.
} 
According to Fethi Bey, who noted during his address in İzmir that the Republican People's Party's statist policies became "clear in Sivas speech", the most important difference between the Republican People's Party's statist policies and their liberal policies were that the Liberal Republican Party would take great care "to not offend the economic factors and production forces." Fethi Bey, who found the prime minister's definition of liberalism incorrect, defined it as follows: "Liberalism is a doctrine which leaves duties of the state to the state and duties of the people to private enterprises and does not approve of any intervention that may hinder the development of these enterprises." What Fethi Bey understood from liberalism was to not obstruct the free development of capital, and to allow entrepreneurs to do business free of state intervention, and he saw it as one of the fundamental reasons behind Europe's development. According to that, state should only intervene in cases of issues individuals cannot handle on their own, and people should not be made to expect everything from the state.

\subsection{Foreign Capital}

When replying to claims of being against foreign capital, İsmet Pasha did not display any image of being radically against foreign capital. He argued that the unfavorable political conditions were the reason behind not sufficiently benefiting from foreign capital and that, under those conditions, foreign capital would do more harm than good. To him, the following was the reason why "constructing railways was not possible by using long-term foreign loans:" "... it is imperative to seek in the state treasury first to meet a nation's need, which bears no delay... If the world is excited by the idea of profit, you seeming impatient as if you cannot stand a one-day delay, will only encourage it to demand severe conditions! Wouldn't these searches and negotiations leave the task, which cannot be delayed even one day, to the mercy of years?" Also noting that he was told to his face by the "most authorized figures" that "Europe hoped to recover all the privileges, it had been denied, by means of the financial crises the Turkish people would suffer from," İsmet Pasha, thus, referred to the famous negotiations between him and Lord Curzon in Lausanne, and attempted to keep alive his image as "the hero of Lausanne."

İsmet Pasha also said that they tried to give various phases of the railway project to Belgian, Swedish and German companies. However, the attempt failed due to different reasons. By saying so, he aimed to show that he did not have any essential or ideological animosity toward foreign capital but he only opposed it on practical grounds and he tried to weaken the opposition's argument: “... I know the business well enough to accept any money that comes with favorable conditions." And then, the Pasha went on to explain that he was not radically against foreign capital, and the conditions under which capital would have a positive impact: "Those, who want to deduce from my words that no capital will ever flow to our country, are deeply mistaken. Capital comes to a deprived and weak country to take possession. It, however, comes to a powerful place, which is not desperately in need, has an unwavering national unity and stability, with reasonable conditions."

In answer to İsmet Pasha's remarks which he paraphrased as "Money came here and did not I accept it?" Fethi Bey stated that the Pasha was also aware that obtaining foreign loans was not possible under the circumstances. Therefore, he said he could not understand "to what opponents the prime minister directed his question". Pointing out that obtaining foreign loans depended on certain conditions which should be fulfilled by the government and that if those conditions were fulfilled, foreign capital would flow to the country through different ways without having to barrow, Fethi Bey also pointed to the negative effects the excessively high 
interest rates had on the people. Here saying that the conditions were not suitable for foreign capital to come but also criticizing the high interest rates seem contradictory because lowering the interest rates when the necessary conditions were not met would leave no appealing motive for the foreign capital. Actually, Fethi Bey knew it as well, since he continued his speech as follows: "I would love to learn why the capital, which settles for very low interest rates in other places, does not come to our country." However, the fact that he also mentioned high interest rates while criticizing the Republican People's Party administration for lack of foreign capital makes one think that it was a populist move aimed at "winning over the crowd".

\subsection{Monopolies}

The monopolies, which was described by İsmet Pasha as "one of our great revenue resources", were generally transferred to private companies and these establishments were granted monopoly privileges over the sales as well. ${ }^{10}$ Therefore, certain state monopolies, given to the supporters of the Republican People's Party in order to create a national bourgeoisie, were criticized by the Liberal Republican Party and its leader Fethi Bey on grounds of being the fundamental reason behind the high cost of living. Mentioning one by one the salt, tobacco, alcohol, match, gunpowder-cartridge-pistol, post-telegram-telephone and port monopolies, the prime minister defended them sometimes demagogically and sometimes sarcastically:

(Salt monopoly) "Which country does not have it? It has been in place for a long time now. Have I put it in practice?"

"If liquor is too expensive, do not drink it. We will gain your health and we will not be upset about losing revenue."

(Match monopoly) "Has it made your life too costly? I am not the one who imposed it; it was my dear friends who oppose monopolies today."

Citing his party's programme during his İzmir speech, Fethi Bey said that they did not mention "post, telegram, telephone and salt monopolies", did not even speak of "the abolishment of tobacco monopolies which need scrutiny", and he listed the monopolies they regard problematic:

"We mentioned abolishing the port monopolies and spoke of sugar and petrol monopolies that have been abolished in name but remained in practice and still have substantial effects on the cost of life." 11

Here, it is noteworthy that İzmir, where the speech was delivered, was home to the most important port in Turkey, that petrol trade was mainly conducted via this port and that the city was close to the lands where sugar beet was cultivated and to sugar production facilities.

\subsection{Financial Management and Taxes}

Among the strongest criticism against the Republican People's Party government and the topics that helped the Liberal Republican Party gain a favorable position in the eyes of the people were financial policies and taxes. Certain articles of the Law on Collection of Assets stipulated that those who did not pay their taxes were to be imprisoned and the Law on Execution and Bankruptcy included similar articles. ${ }^{12}$ Similarly, local people, who could not pay their taxes, were obligated to actively work in the construction of the railway. İsmet Pasha

10 Abdulhamit Avşar, Bir Partinin Kapanmasında Basının Rolü: Serbest Cumhuriyet Fırkası. (İstanbul: Kitabevi,1998), 79-80.

${ }^{11}$ Yunus Nadi, "Fethi Beyin Nutku." Cumhuriyet,September 8,1930

${ }^{12}$ Avşar, Bir Partinin Kapanmasında Basının Rolü: Serbest Cumhuriyet Fırkası,75. 
responded in Sivas to the remarks by the supporters of the Liberal Republican Party targeting such practices: "It is thought that the charm of relieving taxes at the cost of giving upon railways will fascinate the entire nation. The self-deceiving dreams of those who have such hopes prompt my compassion." He then displayed his political style by saying "when we abolished âşar (tithe), it was the countrymen who genuinely hesitated and objected." He then went on to add the councils of alderman "were concerned for the state because such a huge tax was forgone."

Fethi Bey pointed out that the prime minister was trying to parry the issue of tax burden, one of the essential duties of the state, by laying it on specialists as if it was a technical issue. ${ }^{13}$ According to the leader of the Liberal Republican Party, the taxes, they wanted to be relieved as opposed to being lifted, were the ones which undermined the country's competitive power by raising the cost of production, impeded its exports and increased the cost of living. However, the prime minister tried, by ignoring all that, to deny and respond to the claims which the Liberal Republican Party did not undertake. Also stating that it was inappropriate to declare the financial policies, followed for the last 7 years, as "a wonder of success"14, Fethi Bey said that he wanted to ask the prime minister "how many bankruptcies have taken place and how many businesses have been closed down solely because of the income taxes within the last year." He also noted that not the claims of those who executed the policies but statistics proved whether a financial policy was successful or not.

Finally, Fethi Bey, who spoke of the issue of population exchange which was not mentioned in the Sivas speech, noted that the chaos, caused by the not accurately identifying the properties and savings of "nearly half a million" citizens, harmed the country's economy. After praising the people of İzmir, Fethi Bey ended his speech by pointing to Mustafa Kemal's gladness and sensitivities regarding the establishment of the Liberal Republican Party.

İsmet Pasha addressed in his speech in Sivas issues such as "public debts" (düyun-u umumiye), protective policies for the countrymen and domestic industry, analysis of Turkey between 1923-28, the cost of national defense and armament, national currency policy and national policy issue, which were not included in or thoroughly discussed in Fethi Bey's speech in İzmir. Pasha, who addressed to Fethi Bey for the first time by calling him "my dear opponent", said that he "by no means had a thirst for power," and that he was in his position "as a result of the confidence of the deputies of the nation." At the end of his speech, he added that "the results obtained in seven years" and "building such great projects" could only be done "under the leadership of a great Head of the State." "This great project is a new, a nice service, one of numerous, done to the Turkish nation by the Ghazi."

\section{The Rallies' Effects on Political Life}

The process that led to the polarization with the Ghazi and the Republican People's Party on one side and Fethi Bey and the Liberal Republican Party on the other, and the Liberal Republican Party's self-dissolution 2.5 months later. The significance of the Sivas speech lies in the fact that it invigorated the Republican People's Party, which had had no opposition for years, and that the Republican People's Party began to observe relationship between the government and the opposition where it tried to develop compelling arguments in order to defend its actions. İsmet Pasha found the best place and time to kick of such a process: the opening ceremony of the Ankara-Sivas railway on the $7^{\text {th }}$ anniversary of the August 30 Victory

${ }^{13}$ Tekeli and İlkin, 1929 Dünya Buhranında Türkiye'nin İktisadi Politika Arayışları,167.
${ }^{14}$ Tekeli and İlkin, 1929 Dünya Buhranında Türkiye 'nin İkisadi Politika Arayışları,167. 
Day. Fethi Bey, on his part, made a meaningful choice by selecting İzmir, a trade and port city, the country's commercial gateway to the West where the mercantile urban population who were most affected by the economic problems and the luminaries who were uncomfortable with government policies constituted the majority of the residents.

Both leaders mainly discussed topics, which could be seen as weaknesses of the government, in their speeches centering around economy. However, the era of harshness which started with these speeches, would benefit not the Liberal Republican Party but the Republican People's Party.

As it was the case in the example of the Progressive Republican Party, democracy as a notion and phenomenon did not have a central place in political discussions and the administrators and the people did not describe it as a goal to achieve. Despite its importance in terms of the democratic experience in Turkish political history, the establishment of the Liberal Republican Party was, as Teziç says, "an artificial event that was not produced by a movement originating from the people, the base." "The fact that democracy was not included in the 6 arrows which represent the fundamental ideological references of the Republican People's Party and the era can be seen as a sign that the founding cadre of the Republic did not consider democracy as a priority, an essential notion and need. Policies and debates mainly centered around notions such as republic, liberalism, statism, laicism, populism and revolutionism. The word "Republic" was mostly perceived as an umbrella term which also included positive Western values such as liberalism and democracy. It can be though that the phrase of "multiparty political life" or the notion of Republic were used in the first years of the Republic to provide the meaning and the function of the word "democracy". For example, Çetin Yetkin says that republic, to Mustafa Kemal, was not merely a technical term that meant, in its narrow sense, the procedure followed for the election of a president. Mustafa Kemal defined Republic as a "regime that manifests the national sovereignty in the most excellent way." If the word "republic" is replaced with "democracy" here, the meaning would still be the same.

Mahmut Goloğlu says when he initiated the establishment process of the Liberal Republican Party, "Mustafa Kemal Pasha had seen the real reason behind the general discontent in the society and surmised that the only correct and strong measure would be the multi-party political life." ${ }^{\prime 7}$ Around the same time, Mustafa Kemal said the following to Fethi Bey and İsmet Pasha: "Our landscape today is more or less that of a dictator. Despite the fact that there is a parliament, they, at home and abroad, see us as a dictator. German author Emil Ludwig, who paid a visit to Ankara last year, asked me strange questions about our regime. He returned after surmising that we are a dictatorship and then he wrote his opinion. However, I did not establish the republic for my personal gain. We are all mortals. The establishment that will be left behind after I die is an autocratic one. I, on the other hand, do not want to leave behind an autocracy as my legacy to the nation and I do not want to go down in history in that way... What matters is that the republic take root in the country without depending on persons' lives. You should undertake this task. ${ }^{" 18}$ It can be perceived from these remarks that what was meant by republic was close to democracy. Moreover, Mustafa Kemal as clearly afraid of being known as a dictator and wanted to get rid of this accusation, Westerners kept on pointing to, by switching to the multi-party political life as soon as possible. However, the word "democracy", which in

\footnotetext{
${ }^{15}$ Erdoğan Teziç, 100 Soruda Siyasi Partiler. (İstanbul: Gerçek Yayınevi, 1976), 249.

${ }^{16}$ Mustafa Kemal Atatürk, Nutuk. (İstanbul: Türk Devrim Tarihi Enstitüsü, 1981), 322.

${ }^{17}$ Mahmut Goloğlu, Devrimler ve Tepkiler / Türkiye Cumhuriyeti Tarihi 1924 - 1930. (Ankara: Türkiye İş Bankas1 Kültür Yayınları, 1972), 276.

18 Ali Fethi Okyar, Serbest Cumhuriyet Fırkası Nasıl Doğdu Nasıl Feshedildi?, (İstanbul: Derin Tarih Kültür Yayınları,2014)
} 
time would get back its meaning from the notion of republic and would from time to time become its opposite, did not seem to have any significance yet. The case here was seeking solutions in order to counter a very negative reaction and to dismiss an accusation. The quest mostly centered around the notions of liberalism, multi-party political life and republic.

\section{CONCLUSION}

The most basic evaluation of the Sivas and İzmir rallies in terms of political communication is that both "direct", in terms of face to face communication with the people, and "indirect", in terms of delivering the speeches to the masses, who were not present in the rallies, by publishing them in the leading newspapers of the era, communication methods were jointly employed. In this regard, the aforementioned rallies are examples of effective usage of means of mass communication, which in numerous deontological texts assume the mission of establishing and enriching the democratic environment, on the $7^{\text {th }}$ anniversary of the Republic even though it took place during an exceptional interim multi-party period. However, there were events which showed that a problem-free communication may not be possible even in environments such as Sivas and İzmir rallies where direct communication methods were used. For example, during the Sivas speech, where electronic communication systems were not available yet, reporters, located near the podium, typed İsmet Pasha's remarks. However, the noisy crowd, the primitive sound systems and the loud clatter of the typewriters made it difficult to clearly hear what the Pasha was saying. For example, there are different records of İsmet Pasha's remarks of historical importance on statism. Did İsmet Pasha say "What has led us to this direction is our nation's needs and natural inclinations" or did he say "ideological inclinations?" Even though the answer to this question will not cause a momentous historical and political change, it is worth researching and correctly answering at least out of respect for the truth.

The second example is an incident A. Tufan Yazman, who was present at Fethi Bey’s İzmir Rally, told Abdülhamit Avşar:

"Many fanatics, who were yet to embrace the revolutions, spread rumors that Fethi Bey would reinstate old traditions, abrogate the revolutions, throw away the hat and bring back the fez and they began to propagate... Fethi Bey opened his mouth to categorically refute these rumors. The leader had to utter one or two words at a time so that Conker could repeat them to the crowd. Look what a painful incident this method led to:

Fethi Bey - Some people!...

Nuri Conker- (loudly repeats after him) Some people!...

Fethi Bey - [think] we will throw away the hat...

Nuri Conker-[think] we will throw away the hat...

Fethi Bey - Bring back the fez...

Nuri Conker- Bring back the fez...

The crowd did not wait for him to complete the sentence. As soon as they hear the words (we will throw away the hat, bring back the fez...) they began to shout Long Live Fethi Bey with a thundering roar. Maybe 45 thousand people out of the 50 thousand people there threw their hats and caps on the ground and began to trample on them. The stadium was suddenly covered with a cloud of dust. A huge panic arised (among the Liberal Republican Party officials). Fethi Bey changed colors. Nuri Conker and his friends were yelling and stamping ... and trying to warn the people. The chaos lasted a few minutes... And ... finally, Nuri Conker's extremely loud voice echoed across the Alsancak stadium: 
Friends!... There has been a misunderstanding. We will repeat the sentence. Listen!...

... Fethi Bey and Nuri Conker, who was repeating him, finished the sentence as follows by uttering one or two words again:

Some people think we will throw away the hat and bring back the fez. They are wrong. The Ghazi's revolutions will continue!..."19

Among the main difficulties experienced in the rallies in terms of practicing journalism are that audio recording and microphone technologies were yet to be developed, that remarks recorded with typewriters caused certain controversial meanings, that reporters were not properly positioned in terms of the distance between the podium and the crowd. Especially during Fethi Bey's address to 50 thousand people, which was rather crowded given the time of the event, the sound system was insufficient and his messages had to be repeated by criers so that they could be heard from afar. However, this practice led to problems because neither the crowd nor the members of the press could hear his messages well and correctly. In Sivas, the environment was more orderly and favorable for reporters to work than İzmir since the event was an official ceremony on the occasion of August 30 Victory Day and held by the ruling party. However, reporters missed the Pasha's certain remakes there as well because of the noisy typewriters and misquoted him as can be seen in the example of "ideological-natural inclinations." 20

In conclusion, the rallies, held by İsmet Pasha and Fethi bey in Sivas and İzmir respectively to respond to each other prior to the first multi-party local elections in September 1930, are the first examples of a style, which began with the rallies held during the War of Independence and eventually became the most fundamental means in Turkey's political communication history, observed during elections. The tensions that occurred before and after Fethi Bey's speech, and the opening of the path that led to the self-dissolution of the Liberal Republican Party make one think that the democratic environment in Turkey had not matured enough to accept the existence of an opposition party. Political parties' communication with the masses not only boosts their area of influence and power but also widens the democratic political participation. However the fact that the Liberal Republican Party held a grand rally in İzmir and then gained more support than expected in the following local elections paradoxically accelerated its end, and caused the second multi-party political experience (August 12 - November 17, 1930) after the 7-month-long Progressive Republican Party (November 17, 1924 - June 3, 1925) to lead a short life.

\section{BIBLIOGRAPHY}

\section{A. BOOKS:}

AĞAOĞLU, Ahmet. Serbest Fırka Hatıralarl, İstanbul: İletişim Yayınları,1994.

AHMAD, Feroz. The Making of Modern Turkey. Oxfordshire: Taylor \& Francis e-Library, 2003.

ATATÜRK, Mustafa Kemal. Nutuk, Volume I-II, İstanbul: Türk Devrim Tarihi Enstitüsü, 1981.

AVAŞAR, Abdülhamit. Serbest Cumhuriyet Fırkası, İstanbul: Kitabevi Yayınları,1998.

GOLOĞLU, Mahmut. Devrimler ve Tepkileri (1924-1930), Ankara: Türkiye İş Bankası Kültürü Yayınları, 1972.

\footnotetext{
${ }^{19}$ Avşar, Serbest Cumhuriyet Furkası,118-119.

${ }^{20}$ Cumhuriyet, August 31, 1930.
} 
İNAN, Afet. Vatandaş İçin Medeni Bilgiler, Ankara:Milliyet Matbaası, 1930.

OKYAR, Ali Fethi. Serbest Cumhuriyet Firkası Nasıl Doğdu Nasıl Feshedildi?, İstanbul: Derin Tarih, 1987.

TEKELİ İlhan and İLKINN Selim. 1929 Dünya Buhranında Türkiye'nin Íktisadi Politika Arayışları, Ankara: ODTÜ Yayınları, 1983.

TEZİÇ, Erdoğan. 100 Soruda Siyasî Partiler. İstanbul: Gerçek Yayınevi,1976.

\section{B. NEWSPAPERS:}

Cumhuriyet, August 31, 1930.

Cumhuriyet, September 1, 1930.

Cumhuriyet, September 2, 1930.

Cumhuriyet, September 3, 1930.

Cumhuriyet, September 4, 1930.

Cumhuriyet, September 8, 1930. 